\title{
The Higher Education Qualifications Framework and the changing environment of LIS education and training in South Africa: some observations'
}

\author{
Mabel K Minishi-Majanja ${ }^{2}$ \\ Department of Information Science, University of South Africa \\ majanmk@unisa.ac.za
}

\begin{abstract}
Received: 6 October 2009
Accepted: 6 December 2009

Technological, economic and other changes continually reshape the library and information science landscape. In South Africa, the Library and Information Science (LIS) education and training sector is caught up in developments that include new directions in higher education such as the new Higher Education Qualifications Framework (HEQF). This paper provides some observations on the implications of the HEQF on LIS education and training, amid other changes that influence the discipline. While establishing common parameters and criteria for designing qualifications, the HEQF poses challenges to the LIS education needs and practices including names, levels and articulation of qualifications, as well as titles of posts and hierarchies in the workplace. The paper further expounds on the other challenges that need to be simultaneously tackled while reshaping the future. At this critical juncture, the education and training for the information professions in South Africa requires a mixture of ardent focus on understanding the market forces on the one hand, so as to attract students and produce employable graduates and on the other hand a dogged determination to uphold a noble profession in spite of encroaching competition.
\end{abstract}

Keywords: Library and information science education and training; Higher Education Qualifications Framework; South Africa library and information science education; curricular changes in library and information science

\section{Introduction}

The changing patterns of social-economic interaction in society often mean that professions need to re-examine their premise and re-orientate towards current trends and perspectives. Among these patterns, some of the most influential for Library and Information Science (LIS) education are the democratization of information and emancipation of the user (De Bruyn 2007). The democratization of information points to the fact that access to information has long ceased to be the preserve of only a few, that is, the elite, because the political forces on the one hand and Information and Communication Technologies (ICTs) on the other hand have effectively tackled the barriers to information access. I hasten to add that this does not by any means imply that everyone all over the world has equal access, but merely wish to assert that availability and access are better possibilities now than it was 20 years ago. The emancipation of the user is a direct offshoot of both the technology and globalisation. New technologies not only increasingly reach out, sometimes obtrusively, to provide information to the user anywhere and at any time but also employ more user-friendly formats such as sound and images (as opposed to text that had to be deciphered). Globalization permits information users to behave as international citizens looking for and being provided with information across borders, the only inhibiting factor being the issue of relevance which has not been, and might not be completely resolved.

Obviously, these changes have greatly impacted the provision of library and information services and hence the professionals thereof. Services and professionals who provide the services have to both compete and collaborate with some of the new technologies such as Internet services. Undoubtedly, trends in the development of ICTs in the world today are centrally significant to the trends in information services and hence LIS education and training. It is imperative that the types and quality of LIS education graduates should both reflect as well as be a reflection of the types of services provided in the libraries and other information services. Another important contributor to the course of LIS education is the reform or change in higher education. In many countries, governments have recognized the need to reorganize higher education in order to match the changing times and needs, thus impacting LIS education (Hallam \& Calvert 2009; Moniarou-Papaconstantinou \& Tsatsaroni 2008) which is part of the higher education portfolio in many countries. LIS education and training in Africa, having the responsibility of providing qualified staff for the library and information professions, is currently challenged to ensure that graduates have competencies that align the profession with current trends and perspectives but are relevant to the economic and social realities of the continent's inhabitants. Many of the

I. This article is based on conference papers delivered at the $10^{\text {th }}$ DLIS Annual Conference at University of Zululand, I0-II September 2009 and at the LIASA II th Annual Conference at Bloemfontein, 28 September - 02 October, 2009.

2. Mabel K Minishi-Majanja (DPhil) is an Associate Professor and Chair, Department of Information Science, University of South Africa, Pretoria. 
LIS educators also recognize the fact that it is their responsibility to steer the profession towards new directions in response to changing information environment both globally and locally, while at the same time maintaining competitiveness and relevance.

LIS educators worldwide are preoccupied by the question of relevance. In a recent IFLA publication that scans the entire IFLA world (Abdullahi 2009), the 'tunes' about LIS education relevance may differ because of the different social political environments and culture, but the 'lyrics' are the same, basically asking, which way for LIS education? The central theme is that of professional identity especially in a world that now describes itself as the knowledge/information society. De Bruyn (2007: I 14) warns that technological development coupled with the democratization in access to information, key attributes of the knowledge society, are in fact major factors that threaten to erode the profession, inadvertently suggesting that the LIS profession is "sleeping with the enemy." Some of the sub-themes in the debate of the relevance of LIS education include:

- Levels and names of qualifications

- Curriculum approaches and focus (theory vs. practice; academic knowledge vs. technical skills)

- Teaching/learning methods and resources

- Quality

\section{Levels and names of qualifications}

In general, LIS schools in South Africa offer three levels of undergraduate programmes and four levels of postgraduate programmes (Minishi-Majanja \& Ocholla 2004). Undergraduate qualifications include certificates, diplomas and bachelors degree, while postgraduate levels include the postgraduate diploma, honours degree, masters degree and doctoral degree levels. Kyriaki-Manessi (2008) observes that it is more productive to teach LIS at postgraduate level because postgraduate students are bound to already have the academic foundations and hence a better sense of the interdisciplinary nature of the profession. The trend in East Asian countries is towards graduate level education (Miwa 2006) and similarly for Australia (Hallam \& Cravert 2009:293). But in most African countries, the need seems to be for lower qualifications, mainly because the graduates thereof are employed in low-paying positions that cannot afford the salary of a postgraduate. In other words, the recognition of the importance of libraries is not high on the agenda of governments that are still grappling with issues of rampant poverty, poor governance, inadequate healthcare and other basic services. To turn the situation around is a developmental matter that requires appropriate legislation and public interest.

It is observable that the names and nature of LIS education programmes in South Afirca have not been uniform because each and every higher education institution (HEI) determines its own, albeit with approval from the South African Qualifications Authority (SAQA). Looking over the borders, it is possible to affirm Rosenberg's (2000) observation that the lack of uniformity or consistency in names of courses vis-à-vis standards of content and length of study, while a historical accident that is often perpetuated by national or institutional structures and practices, militates against the desire to participate in globalisation. Achieving some uniformity can be useful for equivalence and recognition of qualifications across institutions and across countries, which would not only open the trans-border education barriers, but also facilitate Tammaro's (2007) concern that “more librarians are seeking employment and further education outside their own countries, yet there are no clear guidelines for determining the equivalency of degrees and certificates.

2.1 The South African Higher Education Qualifications Framework (HEQF)

In South Africa, uniformity, not only of LIS education but across all higher education sector is now being heralded by the introduction of the new South African Higher Education Qualifications framework (HEQF), which was signed into law in October 2007 as an amendment to the Education Act. According to the Government Gazette No. 30353 (2007), this is a new policy for education that has replaced three previous policies, i.e. (i) A Qualification Structure for Universities in South Africa - NATED Report I 16 (99/02); (ii) General Policy for Technikon Instructional Programmes - NATED Report I 50 (97/0I); and (iii) Formal Technikon Instructional Programmees in the RSA - NATED I5I (97/0I). This should bring about some uniformity within the country because it "...provides the basis for integrating all higher education qualifications into the National Qualifications Framework and its structures for standards generation and quality assurance." (Government Gazette No. 30353 2007:5). But while seeking to streamline and standardize offerings across the many higher education institutions in South Africa, the HEQF is also disorientating the understanding between LIS educators, students and employers. Gone are the old familiar qualification names such as the National Certificate, National Higher Certificate, National Diploma and Bachelor of Technology, which both the employers and students knew in terms of competency levels. The new names include Higher Certificate, Advanced Certificate, Advanced Diploma and Postgraduate Diploma (Table I). It should be noted that the new names are not merely direct replacements, neither are the qualifications thereof simply equivalents of the old. Like any other innovation or change, it will take time for the stakeholders to become fully famil-

SA Jnl Libs \& Info Sci 2009, 75(2) 
iar with the changes and their implications. Noteworthy also is the fact that both the National Diploma and the Diploma as were previously known have been relegated and instead there is a new diploma that consists of 360 credits that rivals a degree with similar number of credits. The difference between the two is the orientation, with the diploma focusing on the vocational competencies while the degree focuses on the scholastic.

The new framework comes complete with specifications of National Qualification Framework (NQF) Levels that reflect the quality. The NQF exit levels 5, 6, 7, 8, 9 and 10 are representative of the weighting and level of complexity of the content and proficiency after qualification. The framework thus provides for six exit levels of qualifications as shown in Table I.

Table I South African Higher Education Qualifications Framework: qualification types

\begin{tabular}{|l|l|}
\hline $\begin{array}{l}\text { Undergraduate Qualifications } \\
\text { NQF Exit Level 5: Higher Certificate (I } 20 \text { credits) }\end{array}$ & $\begin{array}{l}\text { Admission requirement } \\
\text { National Senior Certificate (NSC) }\end{array}$ \\
$\begin{array}{l}\text { NQF Exit Level 6: Advanced Certificate (I } 20 \text { credits); Diploma } \\
360 \text { credits) }\end{array}$ & $\begin{array}{l}\text { Cognate Higher certificate. } \\
\text { NSC; cognate Higher Certificate or cognate }\end{array}$ \\
$\begin{array}{l}\text { NQF Exit Level 7: Advanced Diploma (I } 20 \text { credits); Bachelor's } \\
\text { degree (360 credits) }\end{array}$ & $\begin{array}{l}\text { Advanced Certificate. } \\
\text { appropriate diploma/ bachelor's degree. }\end{array}$ \\
$\begin{array}{l}\text { NQF Exit Level 8: 'Professional' Bachelor's degree (480 } \\
\text { credits) }\end{array}$ & $\begin{array}{l}\text { National Senior Certificate } \\
\text { National Senior Certificate }\end{array}$ \\
$\begin{array}{l}\text { Postgraduate Qualifications } \\
\text { NQF Exit Level 8: Postgraduate Diploma (I } 20 \text { credits); } \\
\text { Bachelor Honour's Degree (I } 20 \text { credits) } \\
\text { NQF Exit Level 9: Masters Degree (I } 80 \text { credits) }\end{array}$ & $\begin{array}{l}\text { appropriate bachelor's degree. } \\
\text { appropriate bachelor's degree. } \\
\text { appropriate bachelor hons./ professional bachelors } \\
\text { degree; postgraduate diploma. } \\
\text { appropriate master's degree. }\end{array}$ \\
\hline
\end{tabular}

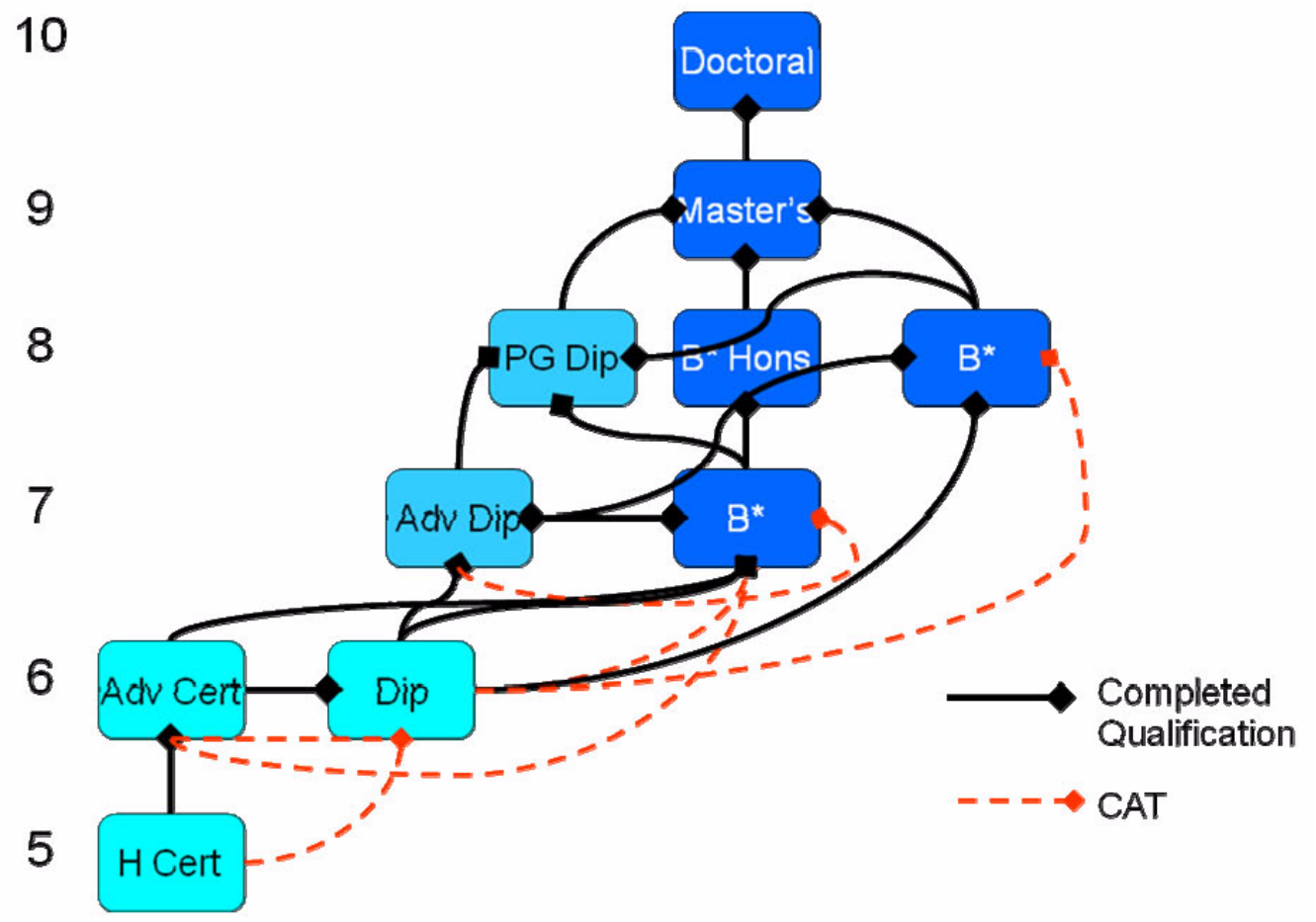

Source: Havenga 2007 (reproduced with permission)

Figure 1 South African Higher Education Qualifications Framework: articulation 
Articulation among the qualifications is depicted in Figure I. Further, to allow for previous achievement to be recognized and contribute to further learning, credit accumulation and transfer (CAT) is factored into the framework. The CAT rule stipulates that "a maximum of $50 \%$ credits of a completed qualification may be transferred to another qualification, provided also that no more than $50 \%$ of the credits required for the other qualification are credits that have been used for a completed qualification." It is important to note that the CAT rule is not universally applicable.

\subsection{Implication for LIS qualifications}

As mentioned before, naming of qualifications has to adhere to the HEQF, thus the discarding most of the hitherto familiar names. Names of qualification will need to have two or three basic components, that is, the qualification type, the designator and the qualifier. Table I shows the various qualification types. A designator has to indicate the broad area of study discipline or profession and has to be used in naming the bachelors' masters' and doctoral degrees only, using the link word "of" e.g. Bachelor of Information Science. Note therefore, that the Bachelor of Arts designates (or signifies) the fact that the broad area of study is "arts" regardless of the subject specification that may follow as qualifier. A qualifier indicates the field of specialization, using the link word "in", e.g. Higher Certificate in Archives and Records Management or Bachelor of Arts in Library Science. A further area of specialization may be indicated by another qualifier e.g. Masters in Information Science in Archival Science. However, the framework further specifies that "in order to use a qualifier, at least $50 \%$ of the minimum total credits for the qualification and at least $50 \%$ of the minimum credits at the qualification exit level must be in the field of specialization denoted by the qualifier" (Government Gazette No. 30353 2007: I I).

Within this new framework, comprehensive universities such as Zululand and the University of South Africa (UNISA) have the luxury of being able to offer qualifications at all levels and of all types. Non-comprehensive universities on the other hand have the luxury to be selective both of level and niche area focus. Thus comprehensive universities run the risk of spreading themselves thin, while non-comprehensive universities run the risk of abandoning some important core LIS areas of practice. South Africa being a society in which equality, affirmative action and economic value are highly prized, it is imperative that LIS educators carefully balance the specifications of the HEQF, scholarship, employers' needs and students' needs.

The implication of these changes is that on the one hand LIS educators have the challenge of ensuring that their offerings and content is comparable without necessarily duplicating each other's programmes. Ostensibly, students should be able to move to a new $\mathrm{HEl}$ and carry the credits of an unfinished qualification from a previous university. On the other hand the employers have to redefine their career progression ladders including both the old and the new (HEQF) qualification descriptions. The old names have to stay because there are individuals still in the workplace who have the old qualifications. Meanwhile, as in the experience of Greece, attitudes may prove the hardest to change (Kyriaki-Manessi 2008).

\subsection{Articulation concerns}

Of greatest concern to LIS education planners is the fact that the vocational/technical route will require a total minimum of 720 credits as compared to the academic/professional route which requires a total of 480 credits to achieve the NQF Exit Level 8. This discrepancy is rather large, even when the credit accumulation and transfer (CAT) rule is applied. It implies a ponderous route to higher qualifications, especially for those who for one reason or another cannot use the bachelor's degree route. Many South African potential LIS students unfortunately fall into this category. In some cases, the potential LIS students may fail to qualify for direct admission to university degree studies. In other cases, potential students may not be able to afford to study for long periods because of family and other commitments. The latter types of students are usually already employed at public or other libraries and archival centres before seeking formal qualification. Such a person would often prefer piecemeal enhancement of their career path through shorter formal qualifications, such as the one year certificates that incrementally become a diploma or degree.

The major problem is that, since there is no articulation provided for articulation from the Advanced Certificate to the Advanced Diploma (Government Gazette Number 303535, 2007:22), a student who has achieved the Advanced Certificate will be forced to first enroll for the Diploma, consisting of 360 credits ( 300 credits with the CAT rule) bringing the total to minimum of 480 credits. From this point it would be unwise to go to the Professional Bachelor's degree which would require another minimum 300 credits bringing the total to minimum of 780 credits to achieve the NQF Exit Level 8 qualification. The route through the "ordinary" Bachelor's degree would require another of $180 \mathrm{credits}$ minimum plus the Honour's degree's 120 credits also bringing the total to minimum of 780 credits to achieve NQF Exit Level 8 qualification. The best route is to articulate from the Diploma to Advanced Diploma, to Postgraduate Diploma, making a total minimum of 720 credits to achieve NQF Exit Level 8 qualification. What would have been more helpful would have been an articulation from the Advanced Certificate to the Advanced Diploma. However, considering that an "advanced" something means that an "ordinary" something has already been achieved, the notion of an advanced diploma without an 
ordinary diploma cannot be acceptable. Besides, part of the purpose of the Advanced Diploma is to enable a change in career path, which has implications for the concepts/contents that have to be included in the curriculum. Thus the only solution would have been a less weighty Diploma.

Clearly, the Diploma of 360 credits is a stumbling block. On the one hand, this Diploma is at the centre of the issues raised in the preceding paragraph. On the other hand, at NQF Exit Level of 6 the Diploma is disproportionately equated to the Advanced Certificate, which can be achieved with a minimum of 180 credits, i.e. half the Diploma's worth.

Another concern is the challenge of making provision for potential students who already have one or several of the previous qualifications such as the National Diploma. Should such a person wish to advance his/her career by obtaining higher qualifications, LIS educators will have to (a) ensure that the person gets enrolled for the appropriate level/ qualification, and (b) try and apply the CAT rule correctly/appropriately in spite of the differences in the modules offered. These issues are likely to reintroduce discrepancies between universities.

\subsection{Industry-related concerns}

Other concerns involve employers of LIS graduates, who will have a hard task in determining where in the corporate hierarchy, to place people with the different qualifications. This will be further complicated with the fact that the industry is replete with people who possess qualifications that are named differently and hence the challenge will be in merging the different designations and finding a common ground/hierarchy. It is imperative that the Library and Information Association of South Africa (LIASA) and other related professional associations/organizations should engage with this matter, alongside LIS educators and employers so as to provide some guidelines for the various institutions and organizations that employ LIS graduates. LIASA's mandate to look after the welfare of librarians and other information professionals places it at the centre of the change.

\section{Curriculum approaches and focuses}

There is no uniform approach to what is taught, let alone how it is taught (Ngulube 2006) in South African LIS education and training. Such an approach has proved difficult considering the dearth of legislation or professional standards on the one hand and the diverse institutional cultures and differentiated expertise. While collaboration could be beneficial, the increasing competition for students often silently militates against it. Collegiality and professionalism has enabled South African LIS educators to share their developments, for instance in conference papers or symposium presentations, but often there is sadly no forum for systematic or collaborative benchmarking of the curricula or even specific modules.

Since politics are not the main focus of LIS educators, one avenue open to them is the use of a learning outcomes/ competencies approach, which can provide a form of communication between the stakeholders involved in the practice and lifelong learning of library and information professionals and those involved with the academic programmes of education and training of library and information professionals." The IFLA Education and Training Section suggests three approaches i.e. programme orientation, educational process orientation and learning outcomes orientation (Tammaro 2005). Programme orientation focuses on the provision of both a broad general education as well as core LIS elements. Most of the university-based qualifications in South Africa have tried to do this, emphasizing an element of graduateness that must be instilled in every student. The educational process orientation is much more difficult to implement uniformly because of varying levels of resources such as lecturers, ICT, library resources, etc. The learning outcomes orientation focuses on what students should learn and are able to learn.

\subsection{Core competencies}

How do we conceive what students need to learn and how do we put it in the curriculum? Raju (2003) observes that the core of LIS education is elusive because of the constant/continuous evolution of the profession. The 10 "core elements"3 listed by IFLA (2000:2) are only the tip of the iceberg, not only because they are general enough not to be prescriptive, but also because by the same token, they are subject to interpretation (e.g. the areas of emphasis), often subject to the knowledge and expertise of the curriculum designers. IFLA advises that LIS education departments "should refer to educational policy statements issued by government or professional associations that identify important knowledge and skill components. (Examples of such statements include those issued by the Institute of Information Science (UK), the Chartered Institute of Library \& Information Professionals - CILIP (formerly the Library Association (UK)), the Special Libraries Association (US), the Medical Library Association (US), the Association of Library Service to Children (US), the Australian Library and

3. IFLA Core elements include: (I)The Information Environment, Information Policy and Ethics, the History of the Field (2) Information Generation, Communication and Use (3) Assessing Information Needs and Designing Responsive Services (4) The Information Transfer Process (5) Organization, Retrieval, Preservation and Conservation of Information (6) Research, Analysis and Interpretation of Information (7) Applications of Information and Communication Technologies to Library and Information Products and Services (8) Information Resource Management and Knowledge Management (9) Management of Information Agencies (10) Quantitative and Qualitative Evaluation of Outcomes of Information and Library Use. 
Information Association (ALIA)." Unfortunately, South Africa does not have clearly identified areas or guidelines as neither LIASA nor the government has made such provisions. Raju's (2003:235) survey in South Africa produced a list of 25 possible subjects for the South African market.

Meanwhile there continues to grow a diversity of fields that are considered as core competencies, which when pitched against the need for market-ready graduates, make the task of preparing a curriculum difficult. For instance, the emergence of ICT as well as Knowledge Management disciplines, effectively jostling for core status, has greatly added to the relevant competencies of LIS graduates. Yet these disciplines are themselves interdisciplinary or adjoining other disciplines and at the same time, still growing. While these new areas cannot be ignored, De Bruyn (2007) contends that the need to accommodate these new areas has resulted in a not too well considered situation, which coupled with the request for adequately skillful graduates, has adverse long term consequences for the profession. In other words, there are many new areas and numerous subjects that are considered core, to the point of overcrowding the curriculum. Considering the guidelines of HEQF, plus the reality that time for studying towards a qualification has specific parameters of duration, 25 basic modules (Raju 2003:235) would prove difficult to fit in one programme. Employers who demand a workplace ready graduate are bound to be disappointed in the short run. This also means that specialization by students during their first qualification is unlikely to take place. Stoker (2000) observes that there is no clear-cut solution to the issues and recommends that educators respond to the employment market by, for instance, offering some of these specialisations as electives and continuing education.

\subsection{Continuing education}

There is great need for continuing LIS education in South Africa because basic professional training is not enough to last five years, leave alone a lifetime in a fast-changing hi-tech profession and world. Ocholla (2003) and Stoker (2000) rightly observe that no one skill will equip an individual at all stages of their career because knowledge and technical skills have a limited span of relevance. AACR2 changes to RDA and Web 2.0 evolves into Web 3.0, requiring the professionals to continually re-skill. Moreover, career development sometimes tends to steer individuals to change focus, for instance from being a reference librarian to a digital librarian or systems librarian. Additionally, employers and employees are no longer finding it affordable to grant/take full time study leave. Thus there is an obvious need for short but effective continuing education programmes that specifically focus on desirable competencies. For this to be effective, it is necessary that educators and practitioners collaborate, especially at the level of identifying the training needs, but also and including facilitating the training. In Australia, the association, ALIA, has formalized continuous education by launching a Professional Development (PD) program (Hallam \& Cravert 2009), while in some European countries, LIS schools provide systematic continuing education. In other countries, it is the larger organizations such as the professional associations that provide (Kajberg, Horvat \& Oguz 2009). In planning continuous education programmes, the educators, employers and practitioners need to remember that the content of continuous education may not always need to add up to complete programmes or enhanced qualification. Desirable and beneficial as higher qualifications may be, in some cases, the acquisition of relevant knowledge or skill may just be encapsulated in one module that is related to a new development either in the profession or specific work environment. The development of continuing education programmes of diverse type, form and duration is imperative, including pegging them to specified NQF levels where possible, for recognition.

\section{Teaching and learning methods}

The integration of new technologies in teaching and learning is said to be a significant factor in promoting academic innovation and transformation, hence influencing the teaching and learning paradigm (Morales \& Roig 2002). There has emerged a new paradigm in university teaching and learning which, among other things, requires university professors/ lecturers to have skills in new forms of instructional technology, in addition to their subject expertise. Academic staff need to be cognizant of, and use the new and variety of learning styles such as active learning, learning to learn, collaborative learning, problem-solving, role playing, etc. which are facilitated by ICTs. They (professors) need to adjust their instructional methods to incorporate the use of ICT-based tools such as tutorial software/courseware, and learn to develop courseware for each course through increased use of ICTs as integrated instructional devices that foster greater hands-on learning, richer simulations, provision of exploratory environments, flexi-time learning, in addition to automated pedagogy (Burbules 2000). The virtual classroom, transcending time and space, the supported self-learning model, allowing a learner to strategize, access core content and respond and the collaborative learning model, involving dynamic horizontal information flow between learners, enabling them to share experiences, are now fully operational. These kinds of educational delivery, sometimes referred to as e-learning presuppose the availability of relevant ICTs and ICT support services. Generally, South African HEls have sufficient levels of ICT diffusion for this to be achieved. What is often a dilemma is the uptake by students as many students have not yet fully developed efficient ICT-based learning skills and 
many more do not have access to ICTs. LIS educators have to balance between incorporating modern teaching methods and marginalising some students.

\subsection{Distance versus contact delivery}

Contact or in-class delivery of an education programme has long held prominence, offering both the learners and the educators opportunities to interact and influence each other in very beneficial ways. Many successful professionals have fond memories of professors whose manner both in and out of class greatly influenced their professional development. The impact of face-to-face interaction is invaluable. Furthermore, the impartation of content, knowledge and skills are more easily managed in contact delivery. But the prospect of earning a qualification without having to relocate or put the rest of one's life on hold, is appealing to many students, especially at higher degree levels. Owen and Leonhardt (2009) observe that distance learning/teaching has gained new heights with the introduction of ICTs and growing enrollments attest to this. It is now increasingly feasible to offer excellent LIS education through synchronous, asynchronous or even hybrid distance education. Considering the economic reality of many South Africans, this latter option should be explored further by LIS educators. However, by the same token, distance delivery offers huge challenges for the student. For example, a typical UNISA student is someone juggling a wide variety of personal circumstances that militate against success. Such a student could be a working mother/father and wife/husband and parent. Such a student could be from a poor background both educationally and socially having little or no resources for proper studying. Then there are the ever present barriers of language proficiencies, self discipline, textual literacy and the absence of positive role models. If a student is at the wrong end of the above challenges, then distance delivery becomes not a solution but a further barrier. Bringing such a student to campus would alleviate some of the challenges such as resources. But it is no panacea since the absence from family is a two-edged sword.

Thus it is clear that both distance and contact delivery have their merits and demerits. The important element is the quality assurance strategies such as appropriate preparation of teaching/learning materials, reorganization of content and access that need to be put in place to maximize the learning. Indeed, whether distance and/or contact delivery, the operative words should be efficiency and throughput.

\subsection{Work Integrated Learning (WIL)}

Some learning is best acquired through real-life experiences and LIS has such work. Such learning is traditionally known by many different terms, such as experiential training, work-integrated/based learning, cooperative education, clinical training, professional practice, supervision, internship, candidacy, etc. In some disciplines, students studying towards a qualification cannot graduate without successful completion of the prerequisite in vivo learning module, often accomplished in a related organisation. Many organisations regard the hosting of students for their in vivo learning as a significant element of the provisioning strategy - with higher acceptances ratios and better yield. Likewise in LIS education, as commented by John Budd (in Pierce 2009:24) at the recent ALISE conference, "If skills and practices are part of the outcomes we want, practitioners are part of the picture".

In a recent survey of South African public libraries training needs, Meyer (2009) found that the different, if not poor library background of library workers is a setback for appointees because the whole environment and ethos is often very unfamiliar to such workers, rendering it an uphill task for them to make sense of the general work, leave alone professional tasks. To support their sense making in the work-related context, library supervisory staff increasingly prefer that Library workers should have some basic understanding of library related tasks and orientation before they embark on a career in LIS. Similarly, LIS education would greatly be enhanced by including a component that enables students to get familiar with real situations. Meyer (2009) observes that "libraries that can support WIL are scattered across the country" but there is no audit of these libraries at the moment. The fact that many public libraries would be willing to participate (Meyer 2009) is imperative that South African LIS educators need to make an audit of these libraries and then enter into agreements with them respecting the logistics of WIL. In accordance with the Department of Education Government Notice No 928, (Government Gazette No. 30353 2007), as policy in terms of the Higher Education Act, South African HEls are obliged to seek hosting partners for the prerequisite in vivo learning of students.

\subsection{Mentoring}

Mentoring is a relationship in which a more experienced person, a trusted friend, a guide, counselor or teacher nurtures and supports a less experience person, novice or student, to learn the profession and gain confidence and expertise through interaction between them. Underwood (2009) observes that a mentor should be a person who is knowledgeable - and able to pass this learning to others, approachable - accessible, friendly and open - and responsible. He further emphasises that "at the core is a relationship of trust by the organisation and by the protégé." Mentorship is one of the most important developmental tools for professional progression often closely linked to productivity, career advancement, and professional satisfaction. In a keynote paper delivered at a recent symposium Underwood (2009) likened mentoring to a 
'bridge' that can enable students to safely cross the 'chasm' between non-knowledge to professionalism. According to Castiglioni, Bellini and Shea (2004), mentoring studies in family medicine, general surgery, pediatrics, and physical medicine and rehabilitation residency programs show mentoring as important for personal growth, definition of career goals, research productivity, and pursuit of academics.

Even though basically a work environment process, mentoring may be used in two types of relationships within LIS education, that is, educators as the mentors of a student on the one hand and on the other hand an experienced professional or practitioner as the mentor of a student worker. The first type of relationship will typically take place in a university or formal education setting, while the second type will take place typically in the workplace. However, it is important to note that even though there are many educators and experienced professionals, not everyone has the necessary skills and motivation to be a mentor. This may result in a heavy mentoring load for the few who have the aptitude, that is, if there are many students or junior staff who need to be mentored. It may be difficult to find the ideal situation but as Underwood (2009) underscores, the rewards are entirely through self-motivation but the quality and success of experience for both mentor and protégé can contribute positively to organisational objectives. Mentoring as a teaching learning method needs to be explored and adapted appropriately albeit alongside other critical resources.

\subsection{Critical resources}

Most studies on LIS education and training tend to focus on curricula and content, often neglecting the question of resources. At the IFLA conference in Durban-South Africa in August of 2007, a heated debate ensued regarding the relative importance (if possible the ranking) of curriculum versus academic staff versus students as factors that influence the quality of LIS education. The debate came to no specific conclusion but it was clear that each of the three components has significance towards the successful achievement of producing good quality LIS graduates. What did not feature strongly in the discussion was the role of resources (e.g. the library and ICT infrastructure and facilities), perhaps not because these are of lesser importance, but more because the three were sufficient variables to content with. Two of the most critical resources that are influential in the quality of LIS education in Africa include quality academic staff and state-of-the-art ICT resources.

\section{Quality assurance and benchmarking}

Many professions have an accreditation process either focused on individuals who must qualify to join the ranks, or focused on the "initiation" process. LIS's accreditation is usually based on the latter, i.e. accreditation of the education and training programmes. The ALIA considers 7 criteria, namely course design, curriculum content, student assessment, staffing resourcing, quality assurance mechanisms and infrastructure. The ALA accreditation programme includes Canada and Puerto Rico and has developed 6 standards that form the basis of evaluation every 7 years. These include the mission, goals and objectives; curriculum; staff; students; administration and funding; resources and facilities (Owens \& Leonhardt 2009:555). Sadly, there are no accreditation programmes in Africa, leave alone South Africa.

\section{Other challenges}

Apart from the HEQF, the challenges facing LIS education in South Africa are neither new nor unique to the country. Among the most prominent are higher education imperatives, professional identity and curriculum issues.

6.1 Competition and the political economy of Higher Education

A "twist in the tale" of LIS education survival is the businessisation of higher education, whereby universities strive to operate as corporate business, with financial viability, if not profit as the bottom line. This poses the danger of eliminating the so-called non-performing departments or programmes, to which LIS may fall victim. Nonperformance among other things refers to the financial viability of a department or programme according to cost units. Cost units are essentially calculated from the number of students, therefore fees received, versus the expense in terms of facilities, resources and human capital expended to run the programme or department. Departments/programmes with few students are usually in danger of being unviable and this is the reason why LIS departments in many parts of the world have had to merge with other departments, so as to survive. By nature of the LIS work, the profession cannot be defined as a large one, at least not until the government legislates the establishment of libraries in every sector and locality. Thus LIS programmes in SA are striving to become more competitive and attractive to students if they are to survive. This often means an increase in ICT modules and the enhancement of management modules at the expense of traditional LIS modules such as classification and cataloging. It is not surprising that some of the departments previously known for LIS education have gone to the extent of totally changing their focus and even name, for example by eliminating the word "Library". While these solutions or attempts at competitiveness are not necessarily bad, they inadvertently further erode the core that shapes the professional uniqueness or identity of LIS. Perhaps it might be better to follow Ribiero's (2008) observation that universities should be made aware that the opportunity to educate/train an information professional is essentially an

SA Jnl Libs \& Info Sci 2009, 75(2) 
important service because such a professional is great asset to society and hence nurturing such a professional is probably a great privilege.

\subsection{Professional identity}

The recognition of a discipline or profession is important for survival both in academic and social contexts. It is instructive that the Australian Library and Information Association (ALIA) presents as the first characteristic of the LIS workforce to "promoting and defending the core values of the profession" (Hallam \& Calvert 2009:289). Part of the professional identity is a function of quality assurance and monitoring through accreditation and approval. These can be accomplished using a verification process of the credibility, authenticity and transferability of the qualifications. In countries where this has been successful, professional associations such as the American Library Association (ALA), Australian Library and Information Association (ALIA), the Chartered Institute of Library and Information professionals (CILIP), etc act as the standards body for education and training. The challenge for South Africa is to enhance LIASA's mandate and standing in order to get the appropriate leadership towards professional identify and quality assurance. Many other professions, including nursing, accountancy, engineering and social work have standards that are influential in curriculum development and the education of their professionals. While appreciating the nobleness of academic autonomy, LIS education would also greatly benefit from direct contribution by one of the two major stakeholders, the body of professionals.

\subsection{Needs of the employment market}

Traditional employers such as libraries require market-ready professionals who will "hit the ground running", i.e. able not only to know the ins and outs of information work, but also have excellent knowledge and skills. Yet the complexity of what librarians do, especially in this era, makes it difficult for education and training programmes to prepare such a "jack of all trades" who is also a master of something. But the issue has to be addressed, otherwise LIS educators will lose students with further dire consequences for the programmes, discipline and profession. The other facet of this problem is the new market of employers who require a new calibre of professional such as knowledge manager, information manager, etc each of which incidentally, may have diverse meaning and interpretation. Such "specializations" are currently attractive but they are still to stand the test of time proving their worth as professional areas. But while they last, LIS educators have to respond to the need.

\subsection{Curricula, educators and students}

As mentioned earlier, there are many areas identified as core competencies in LIS education, to which is continually added new expanding and/or emerging disciplines. On the other hand is the issue of digital divide, especially affecting important constituencies of LIS education such as remote/rural/under-resourced libraries as well as students. Student's learning styles and competency is subject to educational background, in most cases, quite diverse. Even in a well resourced country such as USA, a recent study by Educational Testing Service (2006) in the USA reported that college freshmen lack the essential information literacy necessary to be successful their studies. Generally there is a slow rate of instructional integration of technology and related skills, such as digital literacy, even in the richer (economic or/and technological) countries. Thus the more the curriculum and pedagogy leans toward the new media and world trends, the more certain constituents are marginalized. Should LIS education be bothered about these?

A more hidden problem concerns the educators themselves. LIS educators experience both extrinsic and intrinsic obstacles. Extrinsic obstacles are often institutional and structural while intrinsic obstacles are more in the domain of the individual, i.e., self efficacy. Hardly anyone undergoes training to become a university lecturer or professor. Most of the skills are acquired on the job and through attending relevant forums of discussion. Thus high levels of knowledge in particular subject, even though an important ingredient, does not always translate into good teaching of the subject. Additionally, few LIS educators have had experience as students in a technology-infused environment, to enable them perceive the best way of delivering content.

\section{Opportunity in collaboration}

The LIS educators need to forge more collaboration. It may be instructive to consider the efforts by European LIS educators for intensified consolidation and partnerships as a way of countering the Higher Education reforms and bussinessisation of universities (Kajberg 2007). The European Association for Library and Information Education and Research (EUCLID) obtained funding from the EU to address, among other things, issues of comparability and equivalence of qualifications. The LIS education project which was completed in 2005 has been instrumental in charting the course of European LIS education co-operation and convergence. South African LIS educators can draw from this example first by forming a stable association or chapter within LIASA and work together to apply for NRF funding for projects and/or research. Some of the projects could centre around curricular issues while others could focus on capacity planning and development for information sciences. 


\section{Conclusion}

It is well accepted that the role of librarians and other information workers in mediating technology and community dynamics in order to offer good information services needs to be continually scrutinized. Using new technology effectively to enhance and support communities is a core component of good service. In countries where there is a vibrant LIS profession or at least growing interest in LIS services, there is growth in education programmes. Often this growth or vibrancy is a factor of government and public interest rather than professional attractiveness alongside dedicated professionals. Unlike many professions which are underpinned by the sheer basic necessity for citizens to enlist their help e.g. health, engineering, etc, the LIS profession does not always command government and public buy-in without serious promotion and marketing. Likewise, the education and training for the information professions requires a mixture of ardent focus on understanding the market forces on the one hand, so as to attract students and produce employable graduates and on the other hand a dogged determination to uphold a noble profession in spite of encroaching competition. The HEQF provides a launching pad for greater uniformity among the LIS schools. HEQF “...establishes common parameters and criteria for qualifications design and facilitates the compatibility of qualifications across the system. Within such common parameters, programme diversity and innovation are encouraged" (Government Gazette Number 303535, 2007:5). However, significance of a strong professional association cannot be underestimated. In South Africa, the association should be instrumental in nurturing government and public interest as well as a strong profession. The association can then help to bridge the gap between LIS education and LIS practice.

\section{References}

Abdullahi, I. (ed.) 2009. Global library and information science: a textbook for students and educators. IFLA Publications: I36-I37. Munchen: KG Saur.

Burbules, N.C. 2000. Universities in transition: the promise and challenge of new technologies. Teachers College Record, 102(2):27I-294.

Castiglioni, A., Bellini, L.M. \& Shea, J.A. 2004. Program Directors' views of the importance and prevalence of mentoring in internal medicine residencies. Journal of General Internal Medicine, 19(7):779-782.

De Bruyn, T. 2007. Questioning the focus of LIS education. Journal of Education for Library and Information Science, 48(2): 108II 5.

Educational Testing Service. 2006. College students fall short of demonstrating the ICT literacy skills necessary for success in college and the workplace. [Online]. http://www.etsliteracy.org/portal/site/ets/menuitem.c988ba)e572bada20bc47c392 I509/

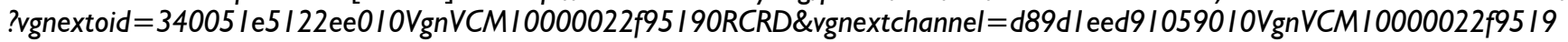
ORCRD. Accessed 22July 2009.

Government Gazette, Number 303535. 2007. (see, South Africa, Department of education, 2007).

Hallam, G. \& Calvert, P. 2009. Australia: LIS Education. In: Abdullahi, I. (ed.) Global library and information science: a textbook for students and educators. IFLA Publications 136-137. Munchen: KG Saur, pp. 288-303.

Havenga, P. 2007. Higher Education Qualifications Framework: a presentation made to the University of South Africa Senate, at Unisa, Pretoria on 12 November 2009 (unpublished).

Hikwa, L. 2006. Integrating information and communication technologies in LIS curriculum in Zimbabwe: a paper presented at the IFLA workshop on integrating ICTs in LIS curriculum in Africa. 2I-23 November 2006 at Safari Court Hotel, Windhoek Namibia.

IFLA. 2000. Guidelines for professional library/information educational programs - 2000. [Online]. http://www.ifla.org/VII/s23/ bulletin/guidelines.htm Accessed 22July 2009.

Ikoja-Odongo, R.J. 2006. Integrating ICTs into LIS curriculum in Uganda. a paper presented at the IFLA workshop on integrating ICTs in LIS curriculum in Africa, 2 I-23 November 2006 at Safari Court Hotel, Windhoek - Namibia.

Kajberg, L. 2007. The European LIS project: an overview. Journal of Education for Library and Information Science, 48 (2):68-8I .

Kajberg, L., Horvat, A \& Oguz, E.S. 2009. Europe: LIS Education. In: Abdullahi, I. (ed.) Global library and information science: a textbook for students and educators. IFLA Publications I36- I37. Munchen: KG Saur, pp. 343-363.

Kyriaki-Manessi, D. 2008. Divergence and convergence within Greek library education: an applied vs a theoretical approach. Education for Information, 26:77-84.

Mambo, H.L. 2000. Africa: focus on current library and information training needs and future patterns. Library Review, 49(8):387-39I.

Manda, P.A. 2006. State of ICTs in LIS curriculum in Tanzania: a paper presented at the IFLA workshop on integrating ICTs in LIS curriculum in Africa, 21-23 November 2006 at Safari Court Hotel, Windhoek - Namibia.

Meyer, H.W.J. 2009. Training of general library workers: challenges facing learning institutions: a paper delivered at the Annual LIS Research Symposium, 30-3I July 2009 at the Unisa School of Business Leadership in Midrand, South Africa.

Minishi-Majanja, M.K. 2003. Mapping and auditing information and communication technologies in library and information science education in Africa: a review of the literature. Education for Information, 2 I: I 59- 179.

Minishi-Majanja, M.K. 2004. Mapping and auditing information and communication technologies in library and information science education in sub-Saharan Africa. University of Zululand (Unpublished thesis).

Minishi-Majanja, M.K. \& Ocholla, D.N. 2004. Auditing information and communication technologies in library and information science education in Africa. Education for Information, 22: 187-22I.

Miwa, M. 2006. Trends and issues in LIS education in Asia. Journal of Education for Library and Information Science, 47(3): I67- I80.

SA Jnl Libs \& Info Sci 2009, 75(2) 
Moahi, K.H. 2006. The Integration of ICTs in the LIS curriculum: Department of LIS, University of Botswana; a paper presented at the IFLA workshop on integrating ICTs in LIS curriculum in Africa, 2I-23 November 2006 at Safari Court Hotel, Windhoek - Namibia.

Moniarou-Papaconstantinou, V. \& Tsatsaroni, A. 2008. Library and information science education in Greece: institutional changes and current issues. Education for Information, 26:85-100.

Morales, L. \& Roig, G. (2002). Connecting a technology faculty development program with student learning. Campus-wide Information Systems, 19(2):67-72.

Ngulube, P. 2006. The state of ICTs in LIS curriculum in South Africa: a paper presented at the IFLA workshop on integrating ICTs in LIS curriculum in Africa, 2 I-23 November 2006 at Safari Court Hotel, Windhoek - Namibia.

Ocholla, D.N. 2000. Training for library and information studies: a comparative overview of LIS education in Africa. Education for Information, 18:33-52.

Ocholla, D.N. 2003. An overview of information and communication technologies (ICT) in the LIS schools of Eastern and Southern Africa. Education for Information, 21 (2-3): I8I-194.

Ocholla, D.N. \& Bothma, T. 2007. Trends, challenges and opportunities for LIS education and training in Eastern and Southern Africa. New Library World, 108(I/2):55-78.

Owen, I. \& Leonhardt, T. 2009. North America: LIS Education. In: Abdullahi, I. (ed.) Global library and information science: a textbook for students and educators. IFLA Publications, I36-I37. Munchen: KG Saur, pp.549-563.

Pierce, J.B. 2009. LIS educators reflect on past and present trends. American Libraries, (March):24.

Raju, J. 2003. The core in library and/or information science education and training. Education for Information, 21:229-242.

Raju, J. 2005. LIS education and training in South Africa: a historical review. South African Journal of Libraries and Information Science, 7I(I):74-84.

Ribiero, F. 2008. LIS education in Portugal between academia and practice. Education for Information, 26:33-42.

Rosenberg, D. 2000. An Overview of education for librarianship in Anglophone sub-Saharan Africa. In Wise, M. (ed.) Education for librarianship and information science in Africa. Denver: International Academic Publishers, pp. I I-33.

Rugambwa, I. 200I. Information science education in sub-Saharan Africa: an analysis. International Information and Library Review, 33:45-67.

South Africa, Department of Education. 2007. The Higher Education Qualifications Framework: Higher Education Act, 1997 (Act No. I0I of 1997). Government Gazette, Number 303535, [and] Government Notice No. 928, 05 October 2007.

Stoker, D. 2000. Persistence and change: issues for LIS educators in the first decade of the twenty-first century. Education for Information. 18(2/3): I15- 123.

Tammaro, A.M. 2005. Report on quality assurance models in LIS programmes.

IFLA: Education and Training Section. [Online]. http://www.ifla.org/VII/s23/index.htm. Accessed 22]uly 2009.

Thapisa, A. 1999a. Developing lasting competencies for a twenty-first century information economy workforce in Africa. Library Management, 20(2):90-99.

Thapisa, A. 1999b. Training for the real working world in the information economy. Library Management. 20(2):84-89.

Underwood, P.G. 2009. On either bank: can mentoring help us? a keynote a paper delivered at the Annual LIS Research Symposium, 30-3I July 2009 at the Unisa School of Business Leadership in Midrand, South Africa.

Weech, T.L. \& Tammaro, A.M. 2007. Feasibility of International Guidelines for Equivalency and Reciprocity of Qualifications for LIS Professionals. [Online]. http://www.ifla.org/VII/s23/projects/23-project-outlines.htm. Accessed 22 July 2009. 